\title{
Factors Affecting Parents Marryed Children in Adolescent Ages in the Kelayan Timur Region Area Banjarmasin Selatan District
}

\author{
Novalia Widiya Ningrum ${ }^{1}$,Elvine Ivana Kabuhung ${ }^{2}$ \\ \{novalia.widiya@gmail.com ${ }^{1}$, elvineivana@gmail.com ${ }^{2}$ \} \\ Universitas Sari Mulia Banjarmasin ${ }^{1,2}$
}

\begin{abstract}
Southeast Asia the data obtained that approximately 10 million children aged under 18 years were married. According to Uniterd Nations Development Economic and Social Affairs (UNDESA), Indonesian ranks 37 among the countries that have the highest number of marriages of young age in the world and even Indonesian ranks second highest in ASEAN. Based on the Indonesian Demographic and Health Survey (IDHS) in 2012, women aged 15-19 who were married in urban areas increased to $32 \%$. Method: an analytic survey with case control approach. The population of this research is parents who marry off children from November 2014 to February 2015 with 22 parents marrying children under the age of 20 yeears and 22 parents marry children over the age of 19. The number of samples 44 . Total Sampling Sampling technique. Data collection by questionnaire. Analysis by chi square test $(\mathrm{p}=0.05)$. Results: Based on data analysis $\mathrm{p}$ count $<\mathrm{p}$ tables hypothesis is accepted, it can be concluded that there is influence between knowledge, education, parents occupations
\end{abstract}

Keywords: Knowledge, education and occupation

\section{Introduction}

Early marriage behavior is strongly influenced by various factors and habits. A UNICEF literacy study found that the interaction of various factors caused children to face marriage at an early age. It is widely known that child marriage is related to tradition and culture, making it difficult to change. (UNICEF, 2005). The results of a UNICEF study in Indonesia in 2002, found the incidence of marriages of 15 -year-old children was around $11 \%$, while those who got married at the exact age of 18 were around 35\%. The practice of early marriage is most prevalent in Africa and Southeast Asia. In Southeast Asia, data show that around 10 million children under 18 are married, whereas in Africa it is estimated that $42 \%$ of the population of children marry before they turn 18. According to the United Nations Economic Development and Social Affairs (UNDESA), Indonesia ranks 37 of the countries that have the highest number of young marriages in the world, even Indonesia ranks second highest in ASEAN, after Cambodia [10]

The National Population and Family Planning Agency (BKKBN) expressed concern because there was an increase in early marriage in urban areas. Based on the 2012 Indonesian Demographic and Health Survey (IDHS), women aged 15-19 years who married in urban areas increased to $32 \%$. When compared with five years ago, the percentage of early marriage in urban areas is $26 \%$ of the total population in this age group. This phenomenon is actually inversely proportional to what happens in the countryside (Hasan, 2012). 
Young pregnant women ( $<20$ YEARS) have a higher risk of postpartum bleeding. This is because at a young age the reproductive organs are not really mature. In addition, the birth canal is still too sensitive so it is easily torn (Elvan, 2012).

Data from the [2] which show the high marriages under the age of 15 in Indonesia are South Kalimantan (9\%) West Java (7.5\%), as well as East Kalimantan and Central Kalimantan respectively $7 \%$ and Banten $6.5 \%$. South Kalimantan ranks third with adolescent marriage ages 15-19 years (48.4\%).According to the Head of the Provincial Health Office the number of early marriages in South Kalimantan reached $9 \%$. This figure is the number of married couples at the age of 15 years. According to the data Riskesdes (Basic Health Research) South Kalimantan is above the national average. The national early marriage rate is only $4.8 \%$, a far cry from South Kalimantan. The high rate of early marriage in South Kalimantan is caused by several factors such as the economy and culture.Based on data obtained from the Regional Office of the Ministry of Religion of the Province of South Kalimantan, from January to December 2014, out of 5 subdistricts in Banjarmasin, South Banjarmasin subdistrict ranked first as noted in the table below.

\section{Research Methods}

This research method uses quantitative observational with case control approach. The study population was taken from all parents who married children under the age of 20 years and aged over 19 years in the period November 2018 to February 2018. Sampling using purposive sampling. The samples in this study were cases and controls. The case is parents who marry children under the age of 20 years, amounting to 22 parents while the control is parents who marry children aged 19 years and over, amounting to 22 parents. The independent variables are knowledge, education, work. The dependent variable is adolescent marriage.

Data analysis methods include univariate analysis of each variable of research results to determine the distribution, frequency and percentage of each variable studied. In addition, bivariate analysis was carried out on two variables that were assumed to be related to the chisquare test.

\section{Results and Analysis}

\subsection{Univariate Analysisa.}

a. Knowledge

Table 1. Distribution of cross tabulations Level of knowledge with age.

\begin{tabular}{lcccccc}
$\begin{array}{l}\text { Knowledge } \\
\text { of } \\
\text { respondents }\end{array}$ & $<20$ yo & $\geq 20$ yo & \multicolumn{2}{c}{ amount } \\
\cline { 2 - 7 } & $\mathrm{N}$ & $\%$ & $\mathrm{~N}$ & $\%$ & $\mathrm{~N}$ & $\%$ \\
\hline Less & 8 & 36,4 & 1 & 4,6 & 9 & 20,5 \\
\hline Enough & 12 & 54,5 & 16 & 72,7 & 28 & 63,6 \\
\hline Well & 2 & 9,1 & 5 & 22,7 & 7 & 15,9
\end{tabular}


$\begin{array}{lllllll}\text { Amount } & 22 & 100 & 22 & 100 & 44 & 100\end{array}$

Table 1 shows that there were 12 knowledgeable parents $(54.5 \%)$ who married children under the age of 20 years.

b. Education

Table 2. Distribution of cross tabulation of education level with age

Knowledge of $<20$ yo $\geq 20$ yo amount

respondents

\begin{tabular}{llllll}
\hline $\mathrm{N}$ & $\%$ & $\mathrm{~N}$ & $\%$ & $\mathrm{~N}$ & $\%$
\end{tabular}

\begin{tabular}{lcccccc}
\hline Basic & 15 & 68,2 & 0 & 0 & 15 & 34,1 \\
& & & & & & \\
\hline Intermediat & 7 & 31,8 & 22 & 100 & 29 & 65,9 \\
& & & & & & \\
\hline High & 0 & 0 & 0 & 0 & 7 & 0 \\
& & & & & & \\
\hline Amount & 22 & 100 & 22 & 100 & 44 & 100
\end{tabular}

Table 2 shows that parents with basic education were 15 people $(68.2 \%)$ who married children under the age of 20 years

c. Occupation

Table 3. Distribution of cross tabulation of occupational level with age

\begin{tabular}{lcccccc}
$\begin{array}{l}\text { Knowledge of } \\
\text { respondents }\end{array}$ & \multicolumn{2}{l}{$\begin{array}{l}<0 \\
\text { yo }\end{array}$} & \multicolumn{2}{l}{$\geq 20$ yo } & \multicolumn{2}{c}{ amount } \\
\cline { 2 - 7 } & $\mathrm{N}$ & $\%$ & $\mathrm{~N}$ & $\%$ & $\mathrm{~N}$ & $\%$ \\
\hline Work & 9 & 40,9 & 17 & 77,3 & 26 & 59,1 \\
\hline Doesn't work & 13 & 59,1 & 5 & 22,7 & 18 & 40,9 \\
\hline Amount & 22 & 100 & 22 & 100 & 44 & 100
\end{tabular}

Table 3 shows that there were 13 unemployed parents $(59.1 \%)$ who married children under the age of 20 years. Based on data analysis of factors affecting parents marrying adolescents with parents' work marrying children at adolescence, the chi square test results obtained $\mathrm{p}$ value $=0.031$. this shows that $\mathrm{p}=0.031<\alpha 0.05$ then $\mathrm{Ha}$ is accepted and Ho is rejected, meaning that there is an influence between parental education and marrying adolescents in Kelayan Timur Kelurahan, South Banjarmasin District. 


\section{Discussion}

\subsection{Level of Knowledge}

Based on the results of research conducted it can be seen that the highest frequency of cases of marrying a 20-year-old child is 12 people $(54.5 \%)$ and over the age of 19 years 16 people $(72.7 \%)$. According to researchers the results show that in the case of parents who are knowledgeable enough it can be because some parents have not gotten enough information about age should marry off children by considering age in terms of reproductive health. At the time of the study there were several respondents who said they had never received any information or guidance regarding the age of marriageThe theory says that there are some bad effects if a child marries in adolescence, one can experience reproductive disorders. Experience is also one of the factors that influence knowledge. This is consistent with the opinion of [8] that one way to get knowledge is experience. In research Lisa Andriani said that knowledge affects parents marry off their children at a young age, the higher the level of one's knowledge the better the parents marry their children at a healthy reproductive age, this result proves there is a significant influence between parental knowledge by marrying adolescent children.

Knowledge is the result of the learning process by involving the senses of sight, hearing, smell, and taste. Knowledge basically consists of a number of facts and theories that enable a person to be able to solve the problems he faces. This knowledge is obtained both from direct experience and through the experience of others.Marriage or marriage is a symbol of an agreement (contract) between a man and woman (in traditional society it also means an agreement between family or clan), on the basis of equal rights and obligations with both parties. A young marriage is a marriage that is performed a pair of teenage boys and girls [5]. A young marriage can also be interpreted as a marriage that is done at the age of adolescents under 16 years in women and under 19 years in men. Factors affecting young marriage among others can be due to the level of education, attitudes and relationships with parents, as a way out of various difficulties, economic pressure and much more.

\subsection{Education Level}

From the research results seen the highest educational outcomes of parents who marry children under the age of 20 years, namely basic education 15 people $(68.2 \%)$ while the highest percentage of parents marrying children aged $>19$ years is medium, namely 22 people $(100 \%)$. On the education variable of parents who marry children under the age of 20 years basic education is higher than other education this could be one of the reasons parents marry children under the age of 20 years, supported by a study that says the level of education a person gets from school can affect one's knowledge the higher one's education the higher his knowledge. Researchers assume this is in accordance with the results of research that illustrates the influence between education and marrying off children in their teens. This can be seen from cases and controls with high education. Parents tend to marry off children over the age of 19 years.Pendidkan means guidance given by someone towards the development of others towards certain ideals that determine humans to act and fill life to achieve safety and 
happiness. Education is needed to get information such as things that support health so that it can improve the quality of life. According to YB Mantra, as quoted by Notoadmodjo, education can influence a person, including one's behavior in lifestyle, especially in motivating the attitude to participate in development.

\subsection{The level of work}

The results showed the highest occupation of parents who married children under the age of 20 years namely not working 13 people $(59.1 \%)$ and the highest occupation of parents who married children over the age of 19 years namely working 17 people $(77.3 \%)$. From the results of the study it can be seen that parents who marry children under the age of 20 more do not work, while the purpose of work is to make ends meet. In the study Darnita said many parents married off children at the age of adolescents because of economic pressure because most parents who do not have a permanent job so as to ease the burden on their parents by marrying their children to people who are considered capable. According to researchers, parents who marry off children over the age of 19 are more likely to be working, with parents who have permanent jobs likely to make parents not in a hurry to marry off a child in their teens. By having a permanent job parents can meet the needs of children such as from basic education to college. That can be one of the prevention of children married at a young age. According to Thomas, quoted by [6], work is an activity that must be done primarily to support their lives and family life. Work is not a source of pleasure, but rather is a way of living that is boring, repetitive and many challenges. Whereas work is generally a time-consuming activity. Working for mothers will have an influence on family life

\section{Conclusion}

Based on data analysis of factors affecting adolescents marrying adolescents with parents' work marrying adolescents, chi square test results obtained $\mathrm{p}$ value $=0.031$. This shows that $\mathrm{p}$ $=0.031<\alpha 0.05$ then $\mathrm{Ha}$ is accepted and Ho is rejected must exist between the education of parents by marrying adolescents in the Kelayan Timur District of South Banjarmasin District.

\section{References}

[1] Anas. 2014. Nikah Dini Jadi Tren Remaja Perkotaan (http://majalahbidan.com/ NikahDini- Jadi-Tren -Remaja-Perkotaan,

[2] BKKBN. 2012.pernikahan dini pada beberapa provinsi di Indonesia: dampak overpopulation, akar masalah dan peran kelembagaan daerah. (http://bkkbn.co.id/pernikahan-dini-pada-beberapa-provinsi-di-Indonesia:dampakoverpopulation-akar-masalah-dan-peran-kelembagaan-daerah,

[3] Fadlyana Eddy. (2009). Pernikahan Usia Dini dan Permasalhannya. Sari Pediatri, 11 (2) Agustus, pp (138)

[4] Hidayat, A. Aziz Alimul. 2007. Metode Penelitian Kebidanan dan Teknik Analisis Data. Jakarta: Salemba Medika.

[5] Kumalasari,intan. 2012. Kesehatan Reproduksi. Jakarta : Salemba Medika 
[6] Nursalam. 2012. Konsep Dan Penerapan Metodologi Penelitian Ilmu Keperawatan: Pedoman Skripsi Tesis dan Instrumen Penelitian Keperawatan. Jakarta: Salemba Medika

[7] Notoadmojo, Soekidjo, 2010. Metode Logi Penelitian Kesehatan Edisi Revisi. Jakarta: Rineka Cipta

[8] Notoadmojo, Soekidjo, 2007. Promosi kesehatan teori dan aplikasi. Jakarta: Rineka Cipta.

[9] Romauli, suryati dan Anna Vida Vindari, 2011. Kesehatan Reproduksi Buat Maha Siswi Kebidanan. Yogyakarta: Nuha Medika.

[10] Santoso, Imam. 2013. Manajemen Data Untuk Analisis Data Penelitian Kesehatan. Yogjakarta: Gosyen Publishing.

[11] Sibagariang, Eva.E. Pusmaika, Rangga dan Rismalinda. 2010. Kesehatan Reproduksi Wanita. Jakarta : Trans Info Media

[12] Wawan. A dan M. Dewi. 2010. Teori Pengukuran Dan Pengetahuan, Sikap Dan Perilaku Manusia Dilengkapi Contoh Kuesioner. Yogyakarta: Nuha Medika

[13] Widyastuti Yani 2010. Kesehatan Reproduksi. Yogyakarta : Salemba Medika

[14] Yanti. 2011. Buku Ajar Kesehatan Reproduksi (Bagi Mahasiswa Kebidanan). Yogyakarta : Pustaka Rihama 